\title{
POWER DISTRICTS: AN EMERGING DEVICE FOR LOW COST ELECTRICITY
}

A PLENTIFUL supply of cheap electricity is vital to the nation's welfare. ${ }^{1}$ Economic stability today demands that electric power, with its tremendous productive potential, ${ }^{2}$ compensate for the diversion of much of the nation's economic plant to military production. ${ }^{3}$ And to improve the standard of living, electricity must continue to fill new needs and supply new conveniences which would otherwise demand an inordinate amount of labor. ${ }^{4}$

Traditionally, the nation's electricity has been provided by private companies under government regulation. ${ }^{5}$ In the electric power industry capital costs are high, and to give the consumer a choice among a substantial number of competing suppliers would require a wasteful duplication of distribution facilities. ${ }^{6}$ Since these circumstances make the electric industry a natural monopoly, regulation was accepted early as a necessary substitute for competition to insure widespread distribution of low-cost electricity.?

1. See President Truman's Economic Message to Congress of December 15, 1950. N. Y. Times, Jan. 9, 1951, p. 4, col. 2. Indeed electric power has been called the nation's number one public utility. Bauer, Why Public Organization of Electric Power? 30 Geo. L. J. 705 (1942). While this may be an exaggeration, the importance of electricity is steadily increasing, its output having doubled between 1940 and 1950. FEDERAL POWER COMMission (hereinafter cited as FPC), WeErcy Electric OutPut in the United States as of SEPT. 30, 1950. But this expansion is still insufficient. MEZERIK, PuRsuit of PleNTY 49-50 (1950); Bonneville Power Administration (hereinafter cited as BPA), Your Columbia River 13, 18 (1950).

2. Each kilowatt hour of electricity is the equivalent of ten hours of human labor. LILIENTHAL, T.V.A.-DEMOCRACY ON THE MARCH 19 (1945). "Every developed horsepower from water brings with it increased wealth to the extent of $\$ 2,500$. With each developed horsepower of electricity there come industrial plants, new homes, new farm houses and new businesses amounting to that sum. PUBLIC UTILITy DISTRICT ResEARCH AND INFoRMATION Service, Commissioners' LetTer Vol. 46, No. 5, Nov. 1, 1946 (quoting Mr. Rufus Woods).

3. In his Economic Message to Congress of December 15, 1950, President Truman pointed out that increased generation of electricity was an important part of the preparedness program. N. Y. Times, Jan. 9, 1951, p. 4, col. 2. Current plans call for tripling present Federal output of hydroelectric power. This program calls for the construction of over one hundred new dams with an ultimate firm power capacity of over seventy-seven billion kilowatt hours. One-third of this program is already under way. DEPARTMENT of THE Interror, Power Project Responsibilities of the Department of Interior (1950).

4. See LiIIenthal, T.V.A.-Democracy on the MARCh 40-2 (1945); BPA, Your Colusibia RIVER 21 (1950).

5. Private companies distribute power in 47 states (Nebraska, where the Power District is firmly entrenched, see page 494 infra, is the 48 th), and are regulated by State Commissions in 40 states. FPC, STaTe Comarission JuRISDICTION (F.P.C. S-60) 2 (1948). In addition, they are subject to FPC regulation if they own a dam on a navigable river, sell power in interstate commerce or transmit power across any public lands of the United States. Federal Water Power Act $\S 4,41$ Stat. 1063 (1920), 16 U.S.C. $\S 791$ (1945), as amended, by Title II of the Public UTILITy ACT of 1935, 49 STAT. 838,16 U.S.C. $\$ 791 \mathrm{a}$ (1945).

6. Troxel, Economics of Public Utmimies 27, 28, 32 (1947).

7. Id. at 8 . 
But regulation has been a weak substitute. ${ }^{8}$ Regulatory commissions, reluctant to impose their own business judgment on private companies, typically do not order rate reductions or extensions of service to high cost rural areas in anticipation of compensating increases in demand. As a consequence rate experimentation has seldom been attempted as a means of reducing the consumer's bill, ${ }^{9}$ and most rural areas remain unserved by private companies. ${ }^{10}$ Because regulation guarantees a fair return on investments ${ }^{11}$ and recovery of operating expenses, it has also failed to provide a driving force toward maximum efficiency. ${ }^{12}$ Finally, conflict between the regulatory objective of cheap power and the private objective of maximum

8. In 1940 the rates charged by regulated and unregulated companies were nearly identical, and in both cases seemed unreasonably high. Twentietr Century Fund, Electric Power and Government Policy 244-5 and Figure IV-9 (1948). As late as 1937, eleven of a sample group of thirty-nine regulated companies were earning more than a fair return on their investment. $I d$. at 208-9. Moreover, prior to the establishment of the Rural Electrification Administration, private companies had done little to extend electric service to rural areas. RuRAL ElECTRIFICATION ADMINISTRATION (cited hereinafter as REA), REPORT OF THE AdMinistrator 13 (1950). This record lends weight to the conclusion that "[s]tate regulation has looked pretty hopeless as a means of holding a private monopoly to its public functions." Bauer \& Costello, Public Organization of ElecTRIC Power 41 (1949). For a general critique of rate regulation, see BAUER, TRANSForming Public Utility Regulation (1949).

9. However, TVA experience indicated the encouraging potentialities of rate experimentation as a method of developing profitable consumer demand. See LILIENTHAL, T.V.A.-DeMrocracy on THE MaRCH (1945). But this evidence has been largely ignored by private companies and state regulatory commissions. Lewis, The Government as Competitor: The Effect on Private Investment, 29 Am. Econ. Rev. 286, 295-6 (1939).

10. In Oregon, for example, rural customers comprise only $4.7 \%$ of those served by the private companies, and in Washington, 6.5\%. FPC, Statistics of ElEctric Utrlities (F.P.C.S-73), 329-30, 337-8 (1949). See also BPA, Service Areas-Private ComPANIES (Map) (1950). And prior to the enactment of REA, private companies under regulation served only $10.9 \%$ of the nation's farmers. REA, REPORT OF THE ADMINISTRATOR 13 (1950).

11. The value of a company's investment may be calculated in any of several ways. The propriety of these methods has been one of the major battlegrounds of the regulatory process. In 1898 the Supreme Court laid down the "fair value" rule, Smyth v. Ames, 169 U.S. 466 (1898), which was to plague regulation until repudiated in FPC v. Hope Natural Gas Co., 320 U.S. 591 (1943).

For a comparison of Ohio's reproduction cost rate base with the FPC "prudent investment value" see $i d$. at 596-7. And for the valuation methods used in the several states see FPC, State Commission Jurisdiction and Regulation of Electric and Gas Utilities 8 (1948).

12. While regulated companies have somewhat lower costs than unregulated companies, the former's costs are still too high. Since a given company may avoid examination of its costs for long periods of time, the disallowance of unreasonable costs may come years after they were incurred. Twentieth Century Fund, Electric Power and Government Policy 238, 244 (1948). State commissions feel, moreover, that their job is done when the private companies are held to a fair return. Fainsod, Regulation and Efficiency, 49 YALE L. J. 1191, 1208-9 (1940). Finally, "the present system of regulation offers many inducements to utility managements to maximize their profits by litigation and few inducements to reduce their costs through efficient operation." $I d$. at 1209. 
profits ${ }^{13}$ has bred prolonged litigation, ${ }^{14}$ making prompt and decisive rate adjustments impossible.

The alternative to regulation is public ownership. While Federal power projects best exploit the economies of regional development, ${ }^{15}$ areas served by them are few; and cheap electricity, for whatever reasons, is generally unavailable elsewhere. ${ }^{16}$ In the absence of Federal projects low-cost power may be furnished by the states. And the state may distribute federallygenerated power. ${ }^{17}$ State programs must therefore be self-sufficient in the absence of Federal action and capable of integration with existing or future Federal programs. Moreover, they should achieve their goal of low rates without the benefit of government subsidization.

State programs have been predominantly of two types: municipal corporations serving the cities; ${ }^{18}$ and Rural Electrification Administration Cooperatives, established with Federal aid under the REA Act of 1935 to supply rural areas unserved by private or municipal corporations. ${ }^{19}$

But during the past ten years, power districts, designed to serve both urban and rural areas, have become a third important device for local public ownership. ${ }^{20}$ In twelve states, ${ }^{21}$ power districts, as public corporations, are

13. It has been argued that the conflict is inevitable as long as the electric power industry is privately owned. See Bauer, supra note 1 , at 722.

14. Lewis, supra note 9, at 295. For a good example of drawn-out litigation, see McCart v. Indianapolis Water Co., 302 U.S. 419, 423 (1938), and Note, The East Ohio Gas Company Litigation, 64 HARv. L. REv. 464 (1951), discussing the twenty year running battle between that company and the city of Cleveland.

15. Since regional areas do not follow state boundaries the Federal Government is best equipped to develop the resources of an entire region.

16. Rates in the areas served by the Tennessee Valley Authority and the Bonneville Power Administration were far below those in the rest of the country. See FPC, TyPICAL Electric Bills (F.P.C.R-40) (1950) and FPC, Typical Residential Bills, Cities (F.P.C. R-41) VII, Chart D (1950).

17. Congress has given preference to public bodies in the purchase of federal power. Graham, The Central Valley Project: Resource Development of a Natural Basin, 38 CALIF. L. Rev. 588, 623 (1950).

18. See Troxel, op. cit. supra note 6 , at 667 .

19. 49 STAT. 1363 (1935), 7 U.S.C. $\$ 901$ (1945).

20. In addition to the objective of extending cheap electric service, a desire to eliminate the political influence of private companies from state affairs may have been an important motivation for the power district laws. See e.g., the speech of former Oregon Governor Meir in 1930, quoted in HerzeN, Power 30-1: "Our country is now in the clutch of the power octopus. . . . It infuences legislation at our national capital and controls legislatures and city councils. . . . It subsidizes the press, civic organizations, and public schools, colleges and pulpit. ... Public development means the preservation of our power sites-their development for the benefit of the people-power at cost for light, heat and industryprogress and industrial expansion. . . . Let us develop it for the people's benefit, and forever liberate Oregon from the stifling domination of the private power monopoly."

21. See Ala. Code Ann. tit. 18, § 1 (1940), § 77 (Supp. 1947); Ariz. Code ANN. \$ 75601 (1939), \$ 75-619a (Supp. 1949); Calif. General Laws acts 6390-3 (Deerings 1944); Miss. Code Ann. tit. $21 \S 5439$ (1942); Neb. Rev. Stat. §70-601 (1943); Nev. Comp. Laws § 5180.01 (Supp. 1931-1941); Oreg. Const., Part XI, § 12, Oreg. Comp. Laws ANn. 
empowered to generate, transmit and distribute electricity within given subdivisions. They are authorized to acquire the necessary facilities and operate them on a self-sustaining basis. They may issue bonds, make contracts, employ staffs, and, in some states, exercise a limited taxing power.

Private electric companies have fought the districts tooth and nail. They have spent large sums both to oppose the passage of district enabling acts and the formation of districts under those acts. ${ }^{22}$ In a single year, for example, the private companies of two states spent nearly one million dollars to fight the district movement. ${ }^{23}$ Despite this opposition, however, the power districts of Nebraska, Oregon, and Washington ${ }^{24}$ have developed sufficiently to be proper subjects of analysis. ${ }^{25}$ Their records point out the potentialities of the district as a technique for obtaining low-cost electricity, and the pitfalls to be overcome if that technique is to be successful.

\section{Area Coverage}

\section{The District Idea}

The major purpose of a public power program is to serve high-cost rural as well as low-cost urban areas as cheaply as possible. To achieve this goal,

\$114-201 (1940), §114-202 (Supp. 1943), § 114-206 (Supp. 1944-7); S. Dak. Laws Spec. Sess., 1950, c. 6; S. C. CODE ANn. \$ 8555-131 (1942); TENn. CODE ANn. \$ 3708.50 (Williams 1934); Wash. Rev. Stat. ANn. \$11605 (1932) (Supp. 1941), §10459-11 (Supp. 1945), $\S 11617-2$ (Supp. 1949); Wrsc. STAT. ch. 198 (1949).

22. Communication to the Yale Law Journar from Mr. Gus Norwood, Executive Secretary Northwest Public Power Association, dated Nov. 17, 1950, in Yale Law Library. This technique is one that has often been used by the private companies to combat public power projects. Mezeruk, The PuRsuit of Plenty 20-26 (1950); Comment, Improving the Legislative Process: Federal Regulation of Lobbying, 56 YALE L. J. 304, 311-12 (1947). In the Northwest the political conflict between public and private has been especially bitter. See, e.g., HANZEN, Power.

23. Most of these expenditures were charged to the consumers as operating expenses through the use of false and misleading records. The companies also made concealed contributions to supposedly impartial organizations which "fronted" for their interests, and made secret payments to prominent citizens some of whom had previously been advocates of public power. Moreover, the FPC found that the companies had every intention of continuing these practices. Northwestern Electric Co., Pacific Power and Light Co., Portland General Electric Co., Puget Sound Power and Light Co., Washington Water Power Co., 2 F.P.C. $369,371-5$ (1941).

24. While there has been no federal project during the life of the Nebraska districts, they are now becoming an important part of the Department of the Interior's program for the Missouri River. N. Y. Times, Dec. 20, 1950, p. 53, col. 3. In Oregon and Washington, on the other hand, the Bonneville Power Administration is the major power generator. These three states, therefore, present a balanced picture of district operations both in the presence and absence of a federal program.

25. In Nebraska the districts first began operations in 1938. Schact, Nebraska's New Coordinated "Cost of Service" Power Supply Program, Proceedings American Public Power Association Seventr Annual Convention 145 (1950). The first Washington districts began operation in 1940. Joun NuveEN \& Co., IT's A FACT 6, Schedule C (1949). Oregon district operations began in 1943. Oregon People's Utility District Directors Association, BuLletin to the Legislators 2 (1947). 
each power development must serve an integrated area-including both urban and rural customers-and be large enough to furnish the optimum economies of size. ${ }^{26}$

Area integration paves the way for immediate service to rural areas at rates which rural customers can afford. When a rural area first receives electric service, the costs of extending that service often cannot be borne by rural customers alone: they are too few and their demand is too small. In an integrated power development new capital costs can be spread among all customers, urban as well as rural; and the latter's rates can be lessened appreciably. Integration offers two additional advantages. First, centrally coordinated plant facilities, capable of providing managerial efficiency and quick adjustments to fluctuations in demand among far-flung rural communities. Second, demand diversification, leading to staggered consumption by different types of consumers during a twenty-four-hour period. ${ }^{27}$ These advantages enable districts to maintain steady power loads and reduce idle capacity, and thereby achieve substantial savings and lowered rates.

Moreover in the long run integration may benefit urban customers as well. Once a rural area is served, demand, stimulated by reasonable rates, will grow, but capital costs will remain the same. Overall unit costs will therefore decline, and the decrease will be passed along to all customers in the form of rate reductions. After a period of steady rural growth, overall rates may be expected to drop below the level which existed before development of the rural area was begun. ${ }^{28}$

The second prerequisite of a successful power project is size. A project must be large enough to withstand the high cost of serving scattered consumers while demand is growing. ${ }^{29}$ In a large development, moreover, financing problems are simplified. And to obtain cheap federal power where available, size may be necessary to help defray the cost of building transmission lines from federal dams to state distribution facilities. ${ }^{30}$

26. See BAuer \& Costello, op. cit. supra note 8, at 165; Troxel, op. cit. supra note 6 at 29.

27. This efficiency is also a product of size. Ibid.

28. This has been the uniform experience of the Washington districts, where rates have steadily declined as the number of customers served has increased. See pages 503-5 infra.

29. Otherwise total unit costs will be too high for the small unit organization while demand is expanding. BAUER \& Costello, op. cit. supra note 8, at 164-6.

30. While Bonneville and TVA transmit the power they produce to distributing companies, Hearings before Senate Committee on Interior and Insular Affairs on National Resources Policy, 81st Cong., 1st Sess. 230 (1949); Troxel, op. cit. supra note 6, at 766, would-be distributors must often construct their own transmission lines. AMrericaN Public Power Association, Weekly Newsletrer 5 (Oct. 13, 1950). The inability of the R. E. A. Cooperatives to build transmission lines for federal power was put forward by them as a major reason for establishing districts in South Dakota. Since preferred users in other states had already demanded more power than the federal dams at Big Bend, Fort Randall, Gavins Point and Oahe could generate, South Dakota could get no federal power without districts with priorities of their own. South Dakota Rural Electric Association, Power 3-4 (1950). 
The efficiencies of integration and size were noticeably lacking in state public power projects prior to the development of power districts. Municipal corporations, designed to serve urban customers, are often cut off from rural areas by law, investment costs, or their own provincialism. ${ }^{31}$ The exclusion of rural areas makes integration impossible and often prevents municipals from achieving the economies of size. ${ }^{32}$ Furthermore, REA Cooperatives are limited to high-cost rural areas, unserved by the private companies and municipals. ${ }^{33}$ Thus cooperatives, like municipals, cannot achieve integration ${ }^{34}$ and often fail to attain optimum size. ${ }^{35}$

Power districts, on the other hand, are restricted neither to urban nor rural areas. Indeed, the district idea is to serve every possible customer through area integration ${ }^{36}$ and to strive for optimum size. ${ }^{37}$

31. TROXEL, op. cit. supra note 6 , at 667-8.

32. Moreover, municipals often lack the technical knowledge necessary to maximum efficiency. $I d$. at 662 . For a discussion of other managerial problems encountered in municipal plants, see $i d$. at 676-8; Bauer, Public Ownership of Public Utilities, 201 Annals 50 (1939); Montgomery, Government Ownership and Operation of the Electric Industry, 201 AnNaLs 43, 47-8 (1939).

33. See note 17 supra. Moreover, they may not duplicate or condemn the facilities of a private company. As a result, they often cannot expand to achieve optimum area coverage. 49 StAT. 1363 (1935), 7 U.S.C. $\$ 902$ (1945).

34. While the achievements of the REA have been commendable, there are farms which cannot be served on a cooperative basis. See BAUER \& Costello, op. cit. supra note 8, at $164-6$.

35. The REA Co-ops serve an average of 3,200 customers, RuRAL Electrification Administration, Report of the Administrator 10 (1950). Private utilities, by contrast, serve an average of 90,000 customers. NAU, Public Power Pays! 7 (1948). See also communication to the Yale LaW Journal from Mr. Wm. A. Dittmer, Power Manager, Bonneville Power Administration, dated Jan. 8, 1951, in Yale Law Library.

In general there has, however, been little conflict between the districts and the REA Cooperatives. The two have usually cooperated in working out their joint problems. Neither is there any substantial evidence that either has interfered with the development of the other. Ibid. In Nebraska the cooperation between districts and cooperatives has been particularly close with the districts supplying most of the power for the cooperatives at exceedingly low rates, King, Nebraska, The Public Power State 19 (1947). And in South Dakota the cooperatives fought for the passage of the Power District Law. See South Dakota Rural Electric Association, Power (1950).

36. The experience of some districts indicates that they may be able to reach every potential consumer. The Wahkiakum County district in Washington serves 1,331 of 1,338 families in the county. Southrwest Washington Public Utility Comaissioners Association, Public Power in Southwest Washington (1950). And the rural Klickitat District has electrified $90 \%$ of the homes and farms in the County, an increase of $69 \%$ in nine years. Public Utility District of Klickitat County, Wn., Power for Better Living 1 (1950).

37. In Nebraska three districts serve the entire state. KIng, Nebraska, The Public Power State (1947). (Reprinted from the March 13, 27 and April 10 issues of the Public UTILITIES FORTNIGHTLY 1947). And in Oregon and Washington the districts serve from 1,331 to 28,293 customers with an average of 8,600 customers per district. Communications to the YALE LAW JourNaL from twelve Oregon and Washington Districts on file in the Yale Law Library. 


\section{Area Limitations}

Although capable of ideal area coverage, districts have often been restricted in practice. ${ }^{38}$ Of the three states where districts have developed, Nebraska has the simplest restriction. The law imposes no size limitation, but provides that a district may not divide any municipality or voting precinct. ${ }^{39}$ In Washington, no district may cross a county line. ${ }^{40}$ But a recent amendment to the statute allows two or more districts to purchase and operate any private utility properties jointly. ${ }^{41}$ The Oregon law is the most complex. While having no size limitation, it forbids division of a municipality. ${ }^{42}$ In addition, municipalities or unincorporated areas located in the heart of a proposed district but voting against it must be excluded from the district. ${ }^{43}$

The Nebraska restrictions are insignificant and have not impeded the development of several large districts, encompassing most of the state. ${ }^{44}$ The Washington county restriction was originally more serious. ${ }^{45}$ Unrelated to optimum service area, it raised a potential barrier to the establishment of appropriately large and integrated districts. ${ }^{46}$ Since the recent statutory amendment, however, it no longer poses a real problem. The districts are now in the process of acquiring, and presumably will operate jointly, the integrated facilities of two of the three private companies in the state. ${ }^{47}$

The Oregon law raises barriers to the establishment of optimum service areas. The provisions for local area exclusions invite the formation of dis-

38. See statutes cited supra, note 21.

39. NEB. REv. Stat. $\$ \$ 70-602$ (1943).

40. Wash. Rev. Stat. ANN. § 11607 (1932).

41. Id. $\S 10459-15$ L. (Supp. 1949). Prior to the amendment the Washington Supreme Court had barred a proposed sale of Puget Sound Power and Light Company's properties to a group of districts. But while the amendment allows the districts to buy as a unit from any private company wishing to sell its properties it is of no help where the private company does not wish to sell.

42. OREg. Comp. Laws ANN. \$114-203 (1940).

43. Ibid. Moreover, no municipality owning an electric plant may be included in an election to form the proposed district without its consent. $I d$.

44. For descriptions of the organization of the Nebraska districts see KING, op. cit. supra note 35; Schact, supra note 25 , at 144.

45. This restriction explains why Washington districts follow county lines. See BPA Service Areas-Public Companies (Map) (1950).

46. The limitation had no economic justification but its effect on the area coverage of Washington districts was slight. "[The] Districts have quite logically arranged systems. In about five instances one P U D does serve adjacent counties when it is logical to do so. This is done by mutual consent. However, . . . I would recommend that in the drafting of any other P U D legislation for other states that the law provide that one or more counties or parts thereof might form P U D's. One of the merits of a county-wide P U D is the tendency of each system to aim at a county-wide rate for $100 \%$ area coverage even in some fairly thin areas." Communication to the Yale Law Journal from Gus Norwood, Executive Secretary, Northwest Public Power Association, dated Nov. 17, 1950, in the Yale Law Library.

47. The two companies presently selling out are Puget Sound Power \& Light and Washington Water Power. Ibid.; N.Y. Times, Feb. 21, 1951, p. 39, col. 6. 
tricts wherein the efficiencies of integration cannot be obtained because they encompass non-contiguous areas. ${ }^{48}$ If the formation of such districts is to be avoided, small districts must be formed instead. Faced with a choice between large, non-integrated districts and small, integrated ones, Oregon has chosen the latter. ${ }^{49}$

\section{FORMATION}

\section{Initiation and Approval}

The procedure for forming a district is detailed in the district enabling act. In all three states it is initiated by a petition signed by a small fixed percentage of the voters registered in the proposed district area. ${ }^{50}$ In Nebraska the petition must be filed with and approved by ${ }^{51}$ the Department of Roads and Irrigation. ${ }^{22}$ In Washington the form of the petition is checked by the County Commissioners for the county in which the district is to be established. ${ }^{53}$ If the petition is in proper form, the proposal is voted on at the next general election. Upon approval by the voters the district is established. ${ }^{54}$

The Oregon law again is the most complicated. A preliminary petition, conforming to minute statutory requirements, must be filed with the Hydroelectric Commission. ${ }^{55}$ The Commission, after a hearing, may recommend changes in the proposal which must be incorporated by the sponsors in a final petition. ${ }^{56}$ The Commission then makes an advisory finding as to the

48. In fact, the establishment of non-contiguous districts seems to be specifically approved by the legislature, OREG. COMP. LAWS ANN. \$ 114-203 (1940).

49. The four Oregon districts which actually conduct operations each encompass an area of one county or less. BPA, SERvice AREAS-Public CoMpanies (Map) (1950).

50. The percentages are as follows: Oregon, 5\%, OrEG. Comp. LAwS ANN., §114-207 (1940); Washington, 10\%, WASE. REv. Stat. ANN., tit. 84, $§ 11607$ (1932); Nebraska, 15\%, NEB. REv. Stat., $\S 70-605$ (1943). These requirements are typical of nearly all the district laws. See statutes cited supra note 21 . For a detailed description of the varying statutory requirements, especially those of Oregon, see Brown, The People's Utility Disiricts in Oregon, 20 OREG. L. REV. 3 (1940).

51. Id. $\$ \$ 70-607,70-608$.

52. Neb. Rev. Stat. \$ 70-603 (1943).

53. The County Commissioners may also modify the boundaries of a district intended to include less than a county. WASH. REv. STAT. ANN. §11607 (1932). But this power has remained dormant since all of the twenty-nine districts formed thus far have included an entire county. Secretary of State for the State of Washington, A Directory of Washington State Public Utility Districts 28-9 (Map) (1950).

54. Wash. Rev. Stat. ANn. $\S 11608$ (Supp. 1941). The legality of the district is then subject to challenge only within six months of the election. Id. $\$ 11616-7$. In such proceedings the Washington courts have not demanded rigid compliance with statutory formalities if all substantive rights have been protected. See, e.g., Vickers v. Schultz, 195 Wash. 651, 81 P.2d 808 (1938) (failure to post election notices properly).

55. OREG. Comp. Laws Ans. $\$ \$ 114-202(5), 114-204$ (1940). In the alternative, a group of municipalities may petition to organize a district, thus dispensing with a petition of the voters. $I d . ~ \$ 114-210$ (1940).

56. OREG. COMP. LAWS ANN. $\$ 114-206$ (1940). While the statutory language with 
feasibility of the proposal, and the plan is placed before the voters. ${ }^{57}$ But victory at the polls does not establish the district. Following the election, the whole procedure must be validated by a court action brought by the district or by any voter. ${ }^{58}$ If the procedure is validated, the district technically is formed.

No doubt the voters should approve or disapprove the formation of a district, ${ }^{59}$ and the failure of Nebraska's law to provide for an election is a serious defect. But the Oregon requirement of two hearings and a validation proceeding sandwiched around the election is complicated and wasteful, and paves the way for almost endless use of dilatory tactics by the district's opponents. ${ }^{60}$ It has, in fact, greatly impeded the formation of districts in Oregon. ${ }^{61}$

A district, though formed, is still impotent. Before it can function it must float bonds to finance the acquisition of operating facilities. In Oregon these bond issues, unlike those of Nebraska and Washington districts, ${ }^{62}$ must be approved by the voters and validated in the courts. ${ }^{63}$ This requirement may lead to great inconvenience. If a district obtains approval of a bond issue before establishing the cost of plant acquisition, the authorization may be insufficient to obtain the necessary properties. ${ }^{64}$ On the other

regard to incorporation of recommendations in the final petition is permissive, $i d . \S 114-$ 220 (1940), it has been interpreted as mandatory. In re People's Utility District, 160 Or. 530,86 P.2d 960 (1939).

57. Oreg. Comp. Laws ANN. $\$ 114-206$ (1940). Each of the steps in this process is governed by numerous technical rules as to notice and other matters, which may encourage lengthy litigation. See, e.g. id. $\$ 114-221$ setting forth various notice requirements.

58. While validation is mandatory before the district may take any action, the statute requires the courts to ignore any procedural irregularities not affecting the substantive rights of the parties. Id. \$114-259 (Supp. 1943).

59. See BAUER \& Costello, op. cit. supra note 8, at 237.

60. Despite the statutory mandate that minor defects be ignored by the courts, masses of litigation have prevented the districts from commencing operations. Of twelve districts formed, between 1933 and 1940, eight have been prevented from operating partly by legal action. The Northern Wasco District, for example, faced three major legal actions between 1939 and 1946. Oregon People's Utility District Directors Assoclation, Bulletin To THE LEgisLators 2 (1947). The legal problems of the district have been multiplied by repeated amendments to the enabling act. Ibid. From the passage of the act in 1933 until 1940 it was amended at every legislative session but one. Brown, People's Utility Districts in Oregon, 20 OREG. L. REv. 3, 8 (1940). It has been amended at least twice since 1940. See supplements to OREG. LAWS.

61. See Oregon People's Utility District Directors Association, op. cit. supra note 60 , at 3 et seg. A proposal by initiative to subject the Washington districts to restrictions similar to Oregon's was defeated in 1939 and again in 1946.

62. Neb. Rev. Stat. $\S \S 70-631$ to 70-633 (1943); Wast. Rev. Stat. ANn. $§ 11611-1$ (Supp. 1941).

63. OREg. CoMrp. Laws ANN. $\$ \$ 114-245(6), 114-259$ (1) (Supp. 1943).

64. On the other hand, if the issue is liberal, the district will be in a weak bargaining position to resist the seller's demands for the full amount of the issue. And in condemnation proceedings the amount of the issue, rather than the fair value of the properties, may determine the award. 
hand, if the acquisition price is established first, ${ }^{65}$ the district cannot act until bonds are authorized; and by that time rising price levels may have rendered the established price obsolete. ${ }^{66}$ Furthermore, the voters may defeat the bond issue because they dislike debts. They may fail to recognize that the bonds to be issued are typically revenue bonds-with principal and interest payable out of the district's income-and do not obligate the taxpayers in any way. ${ }^{67}$ And if the voters defeat the bond issue, funds spent in anticipation of operations will be wasted. The obstructive nature of the bond authorization requirement is illustrated by the fact that of the twelve districts actually formed in Oregon since 1931 only four have commenced operations. ${ }^{68}$

\section{Management}

In Washington and Oregon directors are elected for six and four year terms respectively. ${ }^{69}$ In Nebraska they are appointed by the Governor for a six year term when the district is established, and elected by the districts' voters for an identical term thereafter. ${ }^{70}$ In all three states they receive nominal salaries and work on a part-time basis. ${ }^{71}$ The directors are charged with establishing the general policies of the district and appointing a general manager whom they may remove at will. ${ }^{72}$ The manager supervises actual

65. This price is established either through negotiations with the private company involved or by the jury verdict in a condemnation proceeding. See pages 494-6, infra. But without authorization for a bond issue the district cannot make a firm offer for private facilities. Moreover, if condemnation is employed by the district, the award may be stale and unfair to the private company by the time the necessary bonds are authorized. OREGON People's Utility District Directors Association, op. cit. supra note 60 , at 6,8 .

66. Oregon's Union County District, for example, obtained authorization for a $\$ 925,-$ 000 bond issue, only to find that inflation made it insufficient. Id. at 2 .

67. The otherwise highly successful municipal utility plant of Springfield, Mo., has suffered from just such a public reaction. The voters of Springfield rejected a bond issue necessary for system expansion in 1949 and again in 1950. They apparently feared that increased taxes would result, although state laws bar the use of taxes to pay the interest on such bonds, and revenues were sufficient to make the necessary payments. Communication to the YALE LAw Journal from Mr. C. Sprong, General Manager, City Utilities of Springfield, dated Nov. 14, 1950, in the Yale Law Library.

68. BPA, Service Areas-Public Agencies and Cooperatives (map) (1950). Only two of the districts, Central Lincoln and Clatskonie, have had a fully satisfactory establishment. Oregon People's Utility District Directors Association, op. cit. supra note 60, at 2. The extreme difficulty of Oregon condemnation procedures has also contributed to the weakness of Oregon districts. See page 495 infra.

69. The initial election coincides with the vote on establishing the district. WASH. REv. Stat. ANn. § 1108 (Supp. 1941); OREg. CoMp. Laws ANn. § 114-231 (1940).

70. Neb. Rev. Stat. \$§ 70-609, 70-611 (1943).

71. Neb. Rev. Stat. \$ 70-624.02 (1943); OREg. Comp. Laws ANn. §114-236 (1940);

Wash. Rev. Stat. ANn. \$11616-5 (Supp. 1941).

72. Neb. Rev. Stat. $\$ 70-620.01$ (1943); Oreg. Comp. Laws ANn. $\$ \$ 114-230$ to 114-234, 114-231 (a) (1940 and Supp. 1943); Wash. Rev. Stat. ANn. \$ 11610(j) (1932). 
operations, advises the directors as to policy, and hires subordinate employees. $^{73}$

The district form is well adapted to managerial freedom of action. Unrelated to any political subdivision, district management faces less temptation than management of municipal corporations to charge high rates in order to fill the public coffers. ${ }^{74}$ For the same reason, the districts find it easier than the municipals to avoid making political appointments. ${ }^{75}$ Legislatures could better the districts' managerial structure, however, by giving managers five to ten year appointments and allowing earlier removal only for cause. And the districts themselves could improve the calibre of their managers by raising salaries and qualifications. ${ }^{76}$

\section{PLANT ACQUisition}

Once formed, a district must establish an operating utility system. Construction of a new system, negotiated purchase, or condemnation of the facilities of a private utility are the possible methods of acquisition.

\section{Construction of a Competing System}

Direct competition with a private system is a risky step for a district. Demand may be insufficient to support both competitors. Districts may have trouble in financing, since potential investors may fear the district will collapse under competitive pressure. And the private company, entrenched and able to draw on its entire system for support, may have too great an advantage in the struggle for survival.

Moreover, direct competition will result in complete duplication of facilities. While duplication may lead to lower rates and extended service, ${ }^{77}$ it is an extremely wasteful way of achieving these results and hence should be avoided unless alternative methods of acquisition are unavailable. ${ }^{78}$

73. Neb. Rev. Stat. § 70-620.01 (1943); OrEg. Comp. Laws ANn. § 114-231a (Supp. 1947); Wash. Rev. Stat. ANv. § $11610(\mathrm{j})(1932)$.

74. While many municipal plants have excellent records, some "were an attempt to seize monopoly profits of private companies for the benefit of city treasuries rather than for the consumers of electricity." Montgomery, Government Ownership and Operation of the Electric Industry, 201 AnNaLs 43, 48 (1939). Some municipal utilities have paid well over $50 \%$ of their gross revenues to the towns in which they operated. TROXEL, $o p$. cit. supra note 6 , at 676 .

75. See Bauer, Public Ownership of Public Utilities in the United States, 201 Annals 50, 57 (1939).

76. This course is recommended by the Northwest Public Power Association. Communication to the YALE LAw Journal from Mr. Gus Norwood, Executive Secretary, Northwest Public Power Association, dated Nov. 17, 1950, in Yale Law Library. At present district managers in the Northwest receive anywhere from $\$ 4,800$ to $\$ 10,800$ per year with a median of $\$ 7,500$. Ibid.

77. See Lewis, supra note 9, at 290.

78. Oregon is the only state where districts have resorted to the construction of com- 


\section{Negotiated Purchase}

Negotiated purchase, usually of private facilities, ${ }^{79}$ is the best method of acquisition. It avoids the cost of constructing a competing system, and the litigation cost necessary to condemn. Private companies, however, have been reluctant to sell their profitable holdings, especially to publicly-owned buyers. ${ }^{80}$ This reluctance has been largely overcome in Nebraska and Washington. Nebraska private holding companies, faced with divestment of their operating facilities under the Public Utility Holding Company Act, ${ }^{81}$ sold them all to the power districts. ${ }^{82}$ In Washington two of the three private companies in the state are in the process of selling out to the districts. ${ }^{83}$ In Oregon, however, in spite of the Holding Company Act pressure ${ }^{84}$ negotiated purchase has been an ineffective device..$^{85}$

Failure in Oregon is traceable to the ineffectiveness of Oregon's condemnation procedure. In Nebraska and Washington effective condemnation ${ }^{86}$ has made private purchase of divested facilities hazardous, ${ }^{87}$ and has put the districts in a favorable purchasing position. Oregon districts, however, are unable in practice to condemn, and therefore have no advantage over private interests in the purchase of divested facilities.

peting systems. And there the step is taken only as a last resort. OREgon PeOpLE's Utility District Directors Association, op. cit. supra note 60 , at 3,8 .

79. Generally the districts do not attempt to take over existing municipal and REA projects, but tend rather to cooperate with them in establishing an integrated program. See note 35 supra.

80. See Bunce, The Administration of the Public Utility Holding Company Acr of 1935, pp. 289-90 (unpublished thesis in University of Wisconsin Library, 1949) quoted in Comment, Section 11(b) of the Holding Company Act: Fifteen Years in Retrospect, 59 YALE L.J. 1088, 1118-9, n. 146 (1950).

81. 49 STAT. 803 (1935), 15 U.S.C. $\$ 79 \mathrm{k}$ (b) (1946). Section 11(b), the "death sentence," required the dissolution of the holding company empires. See Comment, supra note 80 , at 1107 .

82. In 1946 the last private company in Nebraska sold its facilities to the Consumers Public Power District. For a history of the acquisition of private plants by the Nebraska districts, see KING, op. cit. supra note 35 .

83. These two companies are Puget Sound Power and Light and Washington Water Power, note 47 supra. The former was a subsidiary of Engineers Public Service Corporation, 15 SEC ANN. REP. 104 (1949), and the latter is part of the American Power and Light system which is undergoing divestment. 16 SEC ANN. REP. 71, 108 (1950).

84. The major companies were subsidiaries of one or another holding company. See Federal Power Commission, Statistics of Electric Utilities in the United States (F.P.C. S-21) 70-2 (1940).

85. See note 66 supra.

86. In Washington eminent domain was used almost without exception prior to the recent sales of Puget Sound Power and Light's and Washington Water Power's properties. Communication to the Yale LAw Journal from Mr. Charles Luce, formerly with the Office of the General Counsel, Bonneville Power Administration, dated Nov. 13, 1950, in Yale Law Library.

87. There are two methods of divestment under the Holding Company Act: open market sale, and stock distributions to holding company shareholders. Both methods involve private purchase of divested facilities. Comment, supra note 80, at 1107. 
A district thus needs two weapons to succeed in negotiating purchases: outside pressure on the private companies to make them sell, and effective condemnation to insure sales to public rather than private interests. Any state can establish an effective condemnation procedure. But the Holding Company' Act, which has provided the necessary outside pressure in the past, is rapidly becoming less important as the required divestments are being completed. $\$$ Negotiated purchase, therefore, cannot be looked to in the future as a reliable means of acquisition. Condemnation must take its place.

\section{Condemnation}

Oregon law makes condemnation extremely hazardous. An Oregon district proceeding by condemnation must pay the private company's costs and attorney's fees if, before commencing the action, it does not offer a price at least as high as the jury finally awards. ${ }^{89}$ No new district could survive such a blow..$^{90}$ Although many districts have been formed in Oregon, few have found a practicable means of acquiring operating facilities. ${ }^{91}$ In Washington, by contrast, districts found condemnation an effective method for obtaining operating facilities even before the advent of Holding Company Act pressure. ${ }^{92}$ Later, when that pressure was felt, condemnation proved effective in stimulating purchases of private facilities divested under the Act.

Condemnation, however, is far from perfect. Costs resulting from the lengthy litigation involved may crush a new district before it can begin operations. And even if the district survives, these costs will be borne eventually by the consumers. The private company, moreover, generally with more to spend on expert testimony than the infant district, ${ }^{93}$ may obtain an unreasonably high award.

88. "Today only 642 registered systems-representing about thirty per cent of the utility industry-have not achieved the geographic integration and corporate simplification required by the Act." Comment, supra note 80, at 1111, citing 15 SEC ANN. REP. 79 (1949). By June 30, 1950, this number had been reduced to 543. 16 SEC ANN. REP. 61 (1950).

89. OREg. Comp. LAws ANn. $\$ 12-410$ (1940). If the district has tendered in advance an amount equal to or greater than that assessed by the jury, then its costs, excluding attorney's fee, must be paid by the private company. Ibid.

90. In one condemnation proceeding for example, these costs would have amounted to $\$ 670,000$, while the average value of Northwest districts is $\$ 3,500,000$. See note 93 infra. Not a single Oregon district has condemned the properties of a private company, OREGON People's Utulty District Directors Association, op. cit. supra note 60, at 7, although districts have been formed since 1933. Id. at 1 .

91. See page 492 and note 68 supra. The two districts which operate successfully in Oregon purchased their facilities from the West Coast Paper Company. OREgon PEOPLE's Utility District Directors Association, op. cit. supra note 60, at 2.

92. Communication to the YaLE Law Journal from Mr. Gus Norwood, Executive Secretary, Northwest Public Power Association, dated Nov. 9, 1950, in Yale Law Library.

93. The amount that private companies can spend on these proceedings seems almost unlimited. Puget Sound Power and Light Company spent $\$ 670,000$ in contesting a con- 
More serious difficulties arise from the very nature of condemnation proceedings. The minimum price which the district can fairly offer is limited to original cost, less accounted depreciation as shown on the company's books. ${ }^{94}$ The private company, by contrast, may ask whatever it pleases. In order to appear reasonable, it generally demands calculated reproduction cost new, less observed depreciation..$^{95}$ But this demand is capable of indefinite expansion, since its component parts are estimates rather than book values. And it is usually raised by the inclusion of severance damages where only part of a system is condemned. Generally, substantial severance damage claims are permitted on the ground that the condemnee suffers injuries above the value of the condemned property by reason of its severance from the remainder of the system. ${ }^{96}$ The net result is that the jury, faced with divergent claims, awards a rough average of the two, and the district often pays too high a price. ${ }^{97}$

To avoid this result, condemnees' demands should be limited. District enabling acts should disallow severance damages. Allowing them is economically unsound, since the condemnee is still guaranteed a fair return on its remaining properties, the base for which has been reduced only by the value of the condemned properties. ${ }^{98}$ Moreover, evidence as to the reproduction cost should be excluded by statute from condemnation trials. The measure of compensation should be original cost of plant less depreciation..$^{99}$ Elimination of the jury trial would further improve condemnation. The technical issues of fact arising in condemnation proceedings should be tried before expert condemnation boards, competent to evaluate the conflicting claims and reach a result fair to both public and private interests. ${ }^{100}$

demnation suit by the Whatcom County (Wn.) District. These expenditures were written of as operating expenses. In the Matter of Northwestern Electric Co. et al., 2 F.P.C. 369, 376 (1941). The average Washington district with a total plant and property value of $\$ 3,500,000$, JoHN NuveEN \& Co., IT's A FAct 6, Schedule B (1949), could not match such expenditures.

94. Communication to the Yale Law Journal from Dr. John Bauer, Director of the American Public Utilities Bureau, dated Nov. 6, 1950, in Yale Law Library.

95. Ibid.

96. Ibid.

97. "There was, of course, in each instance a wide difference between the two valuations, and, as a practical and natural matter, the jury took roughly an average of the two. .. The overvaluations have been substantial." Ibid.

98. The absurdity of severance damages is best shown by an illustration: Five districts each condemn 1/5 of a private company's facilities during a ten year period. Other factors being equal, the company receives more for its facilities than it would if the entire property had been condemned in the first year-despite the façt that it has been earning a fair return on its diminished holdings during the ten years.

99. Where reproduction cost is the regulatory rate base, compensation on an original cost basis may be attacked as failing to cover future earnings lost due to the condemnation. But a district is not seizing a reproduced utility. It is acquiring one actually in existence and condemning the actual investment that brought it into being. Moreover, as a book value rather than an estimate, an original cost base would involve less litigation and opinion evidence than reproduction cost. See, BAUER \& COSTELLO, op. cit. supra note 8, at 154-6.

100. There is no constitutional barrier to such a change. Since regulatory commissions 


\section{Rate Policy}

\section{OPERATIONS}

A district's rate policy determines in large part its ability to fulfill the requirements of a public power program. Enabling acts require only that district rates be set at a level high enough to cover operating costs. ${ }^{101} \mathrm{Be}$ yond this point they establish no rate policy for the districts. Left on their own, the districts may adopt one of three policies. They may seek profit without regard to the rates charged by private companies; set rates as a yardstick for neighboring private companies; or strive for the lowest possible rates. ${ }^{102}$

The profit motive, adopted at times by municipal corporations, ${ }^{103}$ has no place in a public power system where low rates are a basic objective. Profits mean higher rates, and their retention is justified only to provide a surplus for emergencies or plant financing when outside financing is unavailable.

If they set rates on a yardstick basis, the districts in effect become regulators of the private companies through limited competition with them. Regulatory pressure is exerted by the threat of district expansion and by rate comparison, rather than by direct competition for the same established customers. ${ }^{104}$ The yardstick policy, however, requires that the district set its rates at a level which will enable private companies to earn a reasonable profit. It thus abandons the objective of maximum consumption at the lowest possible rates in favor of a regulatory objective. ${ }^{105}$ And in theory it limits public ownership to the number of districts necessary to achieve the desired regulatory effect.

Districts are committed in theory to the third policy-to charge the

customarily set values on utility properties, the condemnation process can hardly be said to demand a jury trial. 1 Nichols, EMINENT Domain $\$ 4.105(1)$ (1950 ed.) and cases cited. The Seventh Amendment, providing for jury trial in "suits at common law," could not be invoked against the states via the due process clause of the Fourteenth since condemnation proceedings are statutory actions rather than suits at common law. United States v. Jones, 109 U.S. 513, 519 (1883); 1 Nichols supra at $\$ 4.105(4)$.

Some state constitutions may, however, present a barrier to administrative determination of condemnation damages. But generally they are no more restrictive than the Federal Constitution. Id. $\$ 4.105(3)$.

101. Oreg. Comp. Laws ANN. §114-233 (1940); NEb. Rev. Stat. § 70-655 (1943); WASE. REv. STAT. ANN. $§ 11611-7$ (Supp. 1941). These requirements are essentially sound. See, BAUER \& Costello op. cit. supra note 8, at 212-13.

102. See TROXEL, op. cit. supra note 6, at 733-4; Lewis, supra note 9, at 290.

103. See Montgomery, Government Ownership and Operation of the Electric Industry, 201 ANNALS 47-8 (1939).

104. While limited competition supplants regulation in a single area, the overall effect is to force price reductions in neighboring areas, and to put pressure on the state regulatory commission to improve the quality of its work. Lewis, supra note 9, at 297; Communication to the Yale LAw Journal from Mr. William A. Dittner, Power Manager, Bonneville Power Administration, dated Jan. 8, 1951, in Yale Law Library. In at least two Washington counties the threat that a district would be established led to rate reductions. Communications to the YaLe LAw Journal from Public Utility District No. 1 of Clark County and Public Utility District No. 3 of Mason County, in Yale Law Library.

105. See Lewis, supra note 9 , at 290. 
lowest possible rates, eschewing profits and paying no heed to rates charged by private companies. ${ }^{106}$ While regulation may result from such a policy, it is incidental to lowering rates, increasing consumption, and maximizing operating efficiency. The low rate policy is the soundest, since these three objectives constitute the raison d'être of a public power program.

Having decided on the lowest possible rates, districts must then decide how to distribute rates among consumers. The first problem is whether consumers distant from the central station should be charged more than those nearby. Private companies charge outlying consumers higher rates ${ }^{107}$ on the theory that cost differences justify it. The districts, on the other hand, are more prone to establish uniform rates for their entire service area. ${ }^{108}$ The district policy is sound. For while long distribution lines cost more than short ones, fixed costs of this type cannot be allocated accurately to any customer or group of customers. ${ }^{109}$ Consumption by distant consumers, moreover, lowers variable unit costs throughout the entire service area. ${ }^{110}$ Increased fixed costs and decreased variable costs should be spread over the entire system. ${ }^{111}$.

The second problem is whether consumers should be charged different rates according to the class of consumption and the amount used. Industrial service costs less than residential because the more constant industrial demand requires less stand-by capacity. And large users are cheaper to serve than small ones. But while some difference in rates is justified by actual cost differentials, ${ }^{112}$ private companies generally discriminate against the small residential user beyond cost justifications. ${ }^{113}$ Such discrimination denies small consumers a full share of the benefits of cheap electricity. ${ }^{114}$

The districts too have discriminated, but to a lesser extent than private companies. ${ }^{115}$ Limited discrimination may be defended on two grounds. It encourages consumption. And to the extent that it brings demand closer to plant capacity it reduces unit costs, leading in the long run to rate reduc-

106. Communications to the YALE LAw Journal from twelve Oregon and Washington Districts, in Yale Law Library. See also Schact, supra note 25, at 144.

107. See FPC, National Electruc Rate Book (Books for Washington and Oregon) (1949).

108. Of the twenty-one districts in Oregon and Washington fifteen charge uniform area rates for residential, commercial, and industrial service. BPA, TyPICAL NET MONTHLY Buls Tables 2-A, 2-B (1949).

109. Twentieth Century Fund, Electric Power and Governatent Policy 670 (1948).

110. Ibid.

111. "[I]t is neither good business or good economics to charge these added costs to the added customers." Id. at 670, n. 207. See also Troxel, op. cit. supra note 6, at 782-5.

112. BAUER \& Costello, op. cit. supra note 8, at 216-17.

113. Id. at 179-80.

114. Ibid. For a criticism of class and promotional pricing see Troxel, op. cit. supra note 6 , at 781-5.

115. See FPC, ElEctric RATE Book (Books for Oregon and Washington) (1950). 
tions. ${ }^{116}$ These justifications can be accepted, however, only if the long run benefits can fairly be expected to exceed the short term gains withheld from small consumers by the discriminatory rate pattern. In making such an evaluation, a district must consider carefully the speculative nature of hoped-for demand increases, the elasticity of demand in the particular area, and the extent of the proposed discrimination.

\section{Financing Capital Investment}

The total cost which district rates cover consists about three-fourths of operating costs and about one-fourth of capital costs. ${ }^{117}$ Operating costs are largely a function of efficiency. Capital costs are determined in part by the cost of plant acquisition and in part by the method of financing capital investment.

The limited taxing power granted the districts by the Oregon and Washington laws ${ }^{118}$ is invaluable to successful financing. While subsidization should be avoided, the formation of districts requires money; and since bonds cannot be issued safely until districts are ready to acquire operating facilities, the taxing power is needed to provide that money. ${ }^{113}$

Once formed, districts finance their capital investments primarily by issuing revenue bonds. The Oregon requirement of voters' approval ${ }^{120} \mathrm{ob}-$ structs construction of extensions and replacements as well as plant acquisition. When replacements and extensions are delayed efficiency declines, costs rise unnecessarily, and rates are affected adversely.

These results can be avoided by financing plant replacements and improvements as well as the amortization of bonds out of operating revenues. The indebtedness is thus retired, while capital investment is maintained at full value, and a debt free, self-supporting district is eventually established. Even where voter approval is not a prerequisite to bond issuance, this practice offers an enticing opportunity to terminate interest charges-an opportunity embraced by many of the Washington districts. ${ }^{121}$

116. TroxeL, op. cit. supra note 6 , at 784.

117. BPA, Combined Totals, Municipals, PUD's and Cooperatives Financial Statements 5 (1950) (hereinafter cited as BPA, Combined Totals).

118. Ore. Comp. Laws Ann. §114-257 (1940); Wash. Rev. Stat. Ann. §11610(g) (1932).

119. The districts have used their tax power for this purpose and have ceased using it once they were firmly established. Communications to the YALE LAW JouRNaL from twelve Oregon and Washington Districts, in Yale Law Library; Secretary of State for The State of Washington, Directory of Washington State Public Utility Districts 56 (1950).

120. ORE. Comp. LAwS ANN. $\$ \$ 114-255,114-259$ (1940).

121. Public Urility District of Benton County, Report to the People 10 (1948), Report to the People 8-9 (1950); Public Utility District No. 1 of Cowlitz County, Commisstoner's Report 9 (1950); Public Utility District of Kilckitat County, Power for Better Living 5 (1950); Public Utulty District No. 2 of Grant County, Anndal Report of the Manager for the Year 19483 (1949). See also FPC, Statistics 
While future financing out of current income may be justified as a means of achieving necessary managerial freedom where the issuance of revenue bonds is severely restricted, it is far from satisfactory as a technique of general application. Current revenues must be adequate to pay off the cost of past equipment and at the same time provide reserves with which to purchase future equipment. This double payment of capital costs increases rates charged during the process. ${ }^{122}$ In effect, consumers are forced to buy an equity in the plant to be enjoyed by future generations. ${ }^{123}$ This can be defended only on the ground that interest payments are so large a cost that their elimination is required even at the price of higher rates to present customers. ${ }^{124}$

Whether or not accompanied by new financing out of current earnings, retirement of district bonds is generally made out of revenues. ${ }^{125}$ It has long been argued, however, that district bonds should be backed by the state's taxing power. ${ }^{126}$ The theory is that tax secured bonds are more acceptable to investors and can therefore be sold at lower rates than bonds secured solely by district earnings. This theory is unsupported by available statistics. In Washington, Oregon, and Nebraska, district bonds carry lower rates of interest than state general obligation bonds. ${ }^{127}$

of Publicly Owned Electric Utmities, 24A, 25 (1948). In $194810 \%$ of the gross revenues of the Washington districts was charged to depreciation; another $10 \%$ was charged to debt amortization. JoHn Nuveen \& Co., IT's A FACT (1949).

122. See Troxel, op. cit. supra note 6, at 674-5; Bauer \& Costello, op. cit. supra note 8 , at 214 .

123. See note 120 supra. The Districts consider the creation of a debt free equity in the people of the district an important and desirable objective, and proclaim it as such. Public Utility Districts Research and Inforafation Service, Some ANswers to Your Questions About Public Utmlty Districts (No date); Southwest Washington Public Utility Commsstoners Association, Public Power in Southwest Washington (1950).

124. Such a position is tenable in view of the fact that interest payments took up $9 \%$ of the operating revenues of four fairly typical Washington districts. For the Benton District $(6,316$ customers) the amount was $9.2 \%$; Cowlitz District $(19,046$ customers $), 7.3 \%$; Grant District (6,136 customers), $10.4 \%$; Klickitat District $(3,776$ customers), $11.0 \%$. PuBlic Utility District of Benton County, Report to the People 8 (1950); Public Utility District No. 1 of Cowlitz County, Commissioner's Report 12 (1950); Public Utility District No. 2 of Grant County, Annual Report of the Manager 1 (1949); Public Utulty District of Kicicitat County, Power For Betrer Living (1950). Interest payments absorbed $9.41 \%$ of the gross revenues of the twenty-four districts purchasing power from Bonneville. BPA, Combined Totals 6.

125. Oregon People's Utiltty District Directors Association, op. cit. supra note 60 , at 4. BAUER \& Costello, op. cit. supra note 8 , at 160.

126. Ibid.; Irons, Services and Costs of Capital Required to Finance Public Ownership, 201 AnNals 17, 18-19 (1939).

127. Washington districts paid an average rate of $2.4 \%$ on their revenue bonds. FPC, Statistics of Publicly Owned Utilimies, (FPC S-77) 24 A, 25 (1948). The rate for all the districts in the Northwest was $2.6 \%$, BPA, Combined Totals 5-6, and is expected to drop to $2 \%$ within 5 years. Communication to the YalE Law Journal from Mr. Gus Norwood, Executive Secretary Northwest Public Power Association, dated November 17, 1950 , in Yale Law Library. 
Even if the lower rate theory is valid, its adoption would strengthen the arguments for the unfortunate practice of voter control over bond issues. And with the state's taxing power behind district bonds, legislatures might tend to restrict rate and service experimentation unduly.

\section{Taxation}

The districts' tax liability is another cost factor which affects the rates charged. Nebraska, Oregon, and Washington districts pay at least as much in local taxes as did their private predecessors. ${ }^{123}$ But they are exempt from the federal corporate income $\operatorname{tax}^{, 29}$ and their bond interest is likewise federally tax exempt. ${ }^{130}$

The districts' favorable tax treatment has been justified on the ground that taxation raises the costs of public power. It has been attacked as giving the districts an unfair advantage over private companies. This attack, however, conceives of public power projects as setting a yardstick for private rates. Since districts reject the yardstick policy and strive to achieve the lowest possible rates, the attack is invalid and federal income taxation of districts unwise. ${ }^{131}$

The rates for the one reported Oregon district and for the Nebraska Districts were obtained from FPC, Statistics of Publicly Owned Electric Utilities (FPC S-77) 14-15, 20 (1948). See Moody's, Governarents and Municipals, 704-11, 1067-72, 1370-98 (1951), for a listing of state general obligation bonds, and district bonds and the interest rates they bear.

128. Oregon districts are subject to the same taxes as their private predecessors. Ore. Comp. Laws ANN. $\$ 114-269$ (1940). The Nebraska districts must make payments in lieu of taxes equal to those made by their private predecessors. NEB. REv. STAT. $\$ \$ 70-651$ to 70-654 (1943). The Washington Districts pay a series of taxes, Wash. REv. Stat. ANN. \$11616-2 (Supp. 1949), which equal $5 \%$ of revenues from all sales of electricity and $3 \%$ on the sale of power that they generate. Over a period of time these taxes exceed those paid by private companies because they increase as district business increases, whereas the private companies paid a static property tax. Secretary of State for the State of Washington, A Directory of Washington State Public Utility Districts 55 (1950).

129. INT. Rev. CODE $\$ 101(8)$.

130. INT. REv. CODE $\$ 22(\mathrm{~b})(4)(\mathrm{A})$.

131. In this endless controversy there are many additional arguments on each side. The major ones for taxation are as follows: (1) The exemption of the districts from federal taxes reduces the sources of tax revenue. (2) The exemption is not balanced by any federal tax limited to consumers of untaxed district power. As a result the burden they avoid is spread over the entire nation. The counter arguments are: (1) Since taxes are paid by consumers in their rates, the exemption does not dry up the actual source. (2) The wealth created by cheap electricity is spread over the entire nation. Cheap electricity, for example, is vital to aluminum production, and for every job created in the Northwest for aluminum reduction nine are created in other parts of the nation. Northwest Public Power Association, The Pacific Northwest Public Power Bulletin p. 2, col. 2 (Aug. 18, 1950).

One of the strongest arguments for the districts' tax advantage is based on their public nature. Taxes are basically contributions to the community. Since all district assets are public property, their profits, whether taxed or permitted to remain with the districts, are contributed to the community as they are used for public purposes. A tax on district income thus changes the form of the contribution. And if its incidence is shifted to consumers via 


\section{Controls}

To insure fulfilment by districts of their objectives, some supervision is necessary. An important question is whether districts, like private companies, should be supervised by state public utility commissions. To date no phase of district operations is controlled by such commissions. ${ }^{132}$ Districts are nonetheless subject to a variety of formal and informal controls. Most operating districts are regulated by some federal agency. Nebraska districts generating hydroelectric power are licensed and regulated by the Federal Power Commission. ${ }^{133}$ Washington and Oregon districts are controlled by the Bonneville Power Administration. ${ }^{134}$ As purchasers of Bonneville power, they must adhere to rate, financial, and accounting regulations established in their contracts with the Administration. ${ }^{135}$

All districts are subject to additional limited controls. Their books are audited by designated state agencies. ${ }^{136}$ Further controls flow from periodic election of directors ${ }^{137}$ and the pressure to meet or beat the rates charged by private companies. ${ }^{138}$

The admirable operating records of the districts indicate that these controls are adequate and that regulation by state commissions is unnecessary. There is no reason to suppose, moreover, that districts created to cut rates to the limit are less conscientious than commissions established for the same purpose. Any system empowering commissions to review the decisions of districts would result in unjustifiable duplication. Indeed, regulation might even prove harmful: regulatory commissions, imbued with caution bred of traditional private practices, might have difficulty adjusting their outlook to the entirely different standards of a publicly-owned company.

rate increases it results in a double contribution by the consumers. See NAU, PUBLIC Power Pays! 17-20 (1948).

132. The Nebraska and Washington districts are specifically exempted. NEB. REV. Stat. \$ 70-656 (1943); WasH. REv. STAT. $\$ 11610(\mathrm{~g})$ (1932). And no overall commission control is mentioned in the Oregon Law. ORE. Comp. LAws ANN. \$114-201 et seq. (1940).

133. Communication to the Yale Law Journal from Mr. J. H. Gutride, Acting Secretary, Federal Power Commission, dated Nov. 10, 1950, in Yale Law Library. Two Washington districts have also applied for FPC licenses. Ibid. As licensees they are subject to regulation under the provisions of the Federal Power Act, 49 STAT. 838 (1935) 16 U.S.C. $\$ 791 a-$ \$25r (1946). Various federal water power acts are collected in FPC, FEderal Power Act (1940).

134. Bonneville Act, $\S 5$ (a) 50 STAr. 731, 734 (1937); 16 U.S.C. $\$ \S 832,832$ (d) (1946).

135. See BPA, General Contract Provisions (GCP Form PUD-7) $\$ \$ 18,19,20$ (1950).

136. Ore. Comp. Laws Ann. § 114-234 (1940); Neb. Rev. Stat. § 70-623 (1943). The books of the Washington districts are audited by the State Department of Municipal Corporations. Communications to the YALE LAW JourNal from the Clark, Grant, Okanagen, Benton, Mason, and Pacific County Districts, in Yale Law Library.

137. See page 492 sutpra.

138. In addition, bond covenants exert some regulatory pressure on district operations. Communication to the YaLE LAw Journal from Mr. Gus Norwood, Executive Secretary, Northwest Public Power Association, dated Nov. 9, 1950, in Yale Law Library. 


\section{OPERATING RECORD}

While committed in theory to maximum rate reductions, the districts have been conservative in applying this policy to their rate structure. ${ }^{139}$ Nonetheless they have greatly reduced rates and increased consumption during their ten years of operations. These rate reductions have had a considerable impact on the practices of private companies operating in the same areas. In the ten year period 1940-50, Washington and Nebraska rates for 250 kilowatt hours - the amount of electricity used monthly in an average home-dropped between three and four times as fast as the national average. ${ }^{140}$ And while Washington's rates dropped from fourth lowest to lowest in the country, and Nebraska's from eighteenth to seventh, ${ }^{141}$ Oregon, where the law has kept the districts out of business, showed relatively small rate reductions. ${ }^{142}$

These figures take on greater significance when compared with those for neighboring states which had similar rates in 1940. Of Washington's neighbors only Oregon's notes were similar enough in 1940 to form a basis for comparison. ${ }^{143}$ Cheap federal power ${ }^{144}$ was a factor in the rate decline in each state, and therefore cannot account for the greater decline in Washington. Moreover, it was not a factor in Nebraska, ${ }^{145}$ where the reductions achieved were unparalleled in any similarly situated neighboring state. ${ }^{146}$ Where the districts actually function, the electric rate level declines.

These achievements stem directly from district rate reductions and in Washington they may also be traced to the competitive pressure exerted

139. This evaluation is substantiated by the rather large net incomes reported by many of the districts to the FPC, see FPC, Statistics of Publicly Owned Utritites 15, 20, 24, 25 (1948), and by the combined Income Statements of the Oregon and Washington districts which indicate that net income for 1949 amounted to $\$ 2,743,307$, or $16.87 \%$ of total operating revenues, BPA, CoMBINED Totals 6 . This may be due in part to the districts' practice of covering both depreciation and the amortization of bonds out of operating revenues.

140. The Washington rates dropped $20.1 \%$ and Nebraska's fell $14.9 \%$ compared to a decline in the national average of 5.3\%. FPC, TyPICAL REsidential Electric BILLS VII, Chart D (1950). The ten districts of Southwest Washington have reduced rates $66 \%$ since they began operations seven years ago. Extension of the Remarks of Hon. Russell V. Mrack, Cong. Rec. Apr. A 5236 (Aug. 1, 1949).

141. FPC, Typical Residential Electric Bills (F.P.C. R-41) VII, Chart D (1950).

142. Oregon rates declined $9.9 \%$, and its ranking fell from second to third. Ibid. At the 100 kilowatt hour level, Oregon's rates declined less than the national average, while Nebraska's and Washington's dropped between two and three times as fast. Id. at VI, Chart C.

143. The wide disparity between Washington, Idaho and Montana rates in 1940 is shown in the FPC figures. Ibid.

144. Eighty eight per cent of all power used by the districts is obtained from the Bonneville Power Administration. Communication to the YalE LAw Journac from Mr. William A. Dittmer, Power Manager, Bonneville Power Administration, dated Jan. 8, 1951, in Yale Law Library.

145. The Nebraska districts generate all of their own power, KING, op. cit. supra note 35 .

146. FPC, Typical Residential Electric Bills (F.P.C. R-41) VI-VII, Charts C and D (1950). Although Wyoming and Colorado rates declined considerably, they were so much higher than Nebraska's in 1940 as to make comparison inconclusive. 
by the districts on private companies. While districts generally refrain from competition with privates for the same established customers, ${ }^{147}$ they do compete with the privates for new industrial customers and subject the privates to the pressure of rate comparison and the constant threat of expansion. ${ }^{148}$ As a result, private companies must approximate district rates or lose their position in a given area. On the other hand, district operations have not adversely affected the privates' ability to earn a fair return on their capital. ${ }^{149}$

Despite reductions, private rates for 250 kilowatt hours are still about seven percent higher than district rates. ${ }^{150}$ While part of the difference may be accounted for by the districts' federal tax savings, this advantage is countered by the greater economies of size available to the privates, ${ }^{151}$ and their reluctance to serve sparsely populated, high cost areas. ${ }^{152}$ Nor does district priority in the purchase of cheap federal power provide the answer.

147. Only two districts compete directly with a private company. These are the Northern Wasco and Tillomook Districts in Oregon which compete with the Pacific Power and Light and Mountain States Power Companies respectively. See FPC, TyPICAL REsidenTIAL ElEctRIC BILLS (F.P.C. R-41) 44 (1950). The rates of both these districts are generally lower for residential, commercial and industrial service than those of the private companies, BPA, Typical Net Montely Bills. Tables 3-B, 4-B and 5-B (1949), although one of the private companies has dropped its rates to compete with the district. Communication to the Yale Law Journal from Mr. William A. Dittmer, Power Manager, Bonneville Power Administration, dated Jan. 8, 1951, in Yale Law Library.

148. Since the summer of 1941 , the private companies presently doing business in Washington have lowered their rates by $14.3 \%$ for 250 kilowatt hours. These rates are listed in FPC, Typical Residentlal Electric BILls (F.P.C. R-41) 58 (1950), and TyPiCAL EleCrRIC BrLls (F.P.C. R-21) (1941). While part of these reductions can be accounted for by technological improvements, there is a high correlation between the timing of the reductions and the beginning of district operations. Nine districts were formed between 1939 and 1941. Communication to the Yale LAw Journal from Mr. William A. Dittmer, Power Manager, Bonneville Power Administration dated Jan. 8, 1951, in Yale Law Library. During this period of rising prices the rate reductions granted by the private companies were greater than at any time between 1935 and 1946. BPA, ANNUAL Resale RATE REDUCTIONS IN WASHINGTON AND OREGON (1947). These reductions ranged between two and three million dollars annually. Ibid.

149. Twentieth Century Fund, Electric Power and Government Policy 730-1 (1948). In fact, the private companies' rates of return have increased slightly since the districts commenced operations. In 1940 the rates of return of the private companies operating in Washington and Oregon were between 4 and $5 \%$. In 1948, the latest year for which complete figures are available, they all earned over $5 \%$. FPC, STATrsTics of ELECTRIC UTILITIES, (F.P.C. S-21) 70-1, 90-1, 170-1, 190-1 (1940); (F.P.C. S-73) 58-9, 74-5, 158-9, $174-5$ (1948).

150. See FPC Typical Residential Electric Bills (F.P.C. R-41) 58 (1950).

151. The three private companies in Washington serve $135,000,268,000$ and 105,000 customers while the largest district serves 28,000 customers. FPC, STATISTICs of ELECTRYC Utulities (F.P.C. S-73) 337, 338 (1948); FPC, Statistics of Publicly Owned Electric UTILITIES (F.P.C. S-77) 25 (1948).

152. Communication to the Yale Law Journal from Mr. Gus Norwood, Executive Secretary, Northwest Public Power Association, dated Nov. 17, 1950, in Yale Law Library. See also note 10 supra. 
Districts have obtained sparse advantage from their priority, since the privates have had little trouble obtaining federal power. ${ }^{153}$ The districts do have one fairly significant advantage over private companies-lower managerial costs - but even this difference is not enough to explain the discrepancy in rates. ${ }^{154}$

Increased consumption has accompanied declining rates. Overall district demand has increased threefold during the ten year period of district operations. ${ }^{155}$ And the districts, together with the REA co-operatives, have extended service to rural areas never served by the private companies. ${ }^{156}$ Finally, public power, by attracting new industries, has increased the wealth and improved the economy of the entire area.

\section{ConClusion}

Power districts, unless crippled by Oregon-type restrictions, are the most effective non-federal public power device yet developed. Despite their limitation to state borders and their consequent inability to achieve the economies of regional development, the districts have extended efficient, low-cost electric service on a financially sound basis. Thus they have achieved the basic objectives of a public power program. And their incidental effect on the private companies has resulted in better regulation than that provided by state commissions.

The success of the Nebraska districts has proved that the technique can be successfully employed by a state in which there is no federal power program. And the Washington experience illustrates that districts are ideally suited to integration into an established or future regional program as distributors of federally generated power. The district technique is one which any state could profitably explore.

153. Since Bonneville and Grand Coulee were built, the Portland Gas and Electric Company has been largest distributor of federally generated power in the Pacific Northwest. Portland General Electric Co., Recommendations for Federat. Power Policy 3 (1950). In the future, however, private companies may have trouble obtaining federal power, since they are no longer assured a steady supply of power from Bonneville. AMrerican Public Power Association, 8 Public Power 10 (Oct., 1950).

154. The districts spend roughly 2 cents less of each revenue dollar than the private companies on managerial expenses. See FPC Statistics of Publicly Owned ElEctric Utilities (F.P.C. S-77) 24A, 25A (1948); Statistics of Electric Utilities (F.P.C. S-73) 437A, 438A (1948).

155. Extension of the Remarks of Hon. Russell V. Mack, 95 Cong. REc. Apr. A 5236, (Aug. 1, 1949). "Today, P U D customers use 3 or 4 times as much power as the average American family." Secretary of State for the State of Washington, A Directory of Washington State Public Utility Districts 55 (1950). The limited Oregon experience has been similar. The Clatskanie District, for example, has experienced a $228 \%$ increase in demand since it began operations. Communication to the YALE LAw Journal from the Clatskanie People's Utility District, in Yale Law Library.

156. Between 1939 and 1949 the percentage of Rural Electrification increased in $\mathrm{Ne}$ braska from 14.6 to $54.5 \%$, in Oregon from 49.3 to $99.3 \%$, and in Washington from 56.2 to $96.6 \%$. REA, Report of the Admintstrator 54 (1940); id. (1949) at 4. See note 36 supra for an example of the district's success in electrifying rural areas. 